\title{
INVESTIGATING FACTORS AFFECTING THE INTENTION TO USE ISLAMIC PERSONAL FINANCING
}

\author{
NIK SAFIAH NIK ABDULLAH \\ NORAZLINA ABD WAHAB \\ Islamic Business School \\ Universiti Utara Malaysia
}

\begin{abstract}
The purpose of this paper was to examine the main factors that influence consumers' intention to use Islamic personal financing. A sample of 308 employees from Universiti Utara Malaysia was surveyed. Attitude, social influence, perceived behavioral control, religious obligation and religiosity were examined towards the intention to use Islamic personal financing. The results show that perceived behavioral control proved to be a strong predictor. The findings of this study provide key inputs to an Islamic bank for better planning of Islamic personal financing facilities.
\end{abstract}

Keywords: Islamic personal financing; intention; usage; shari'ah compliance; religiosity.

\section{Introduction}

As reported by Malaysian Business (2013), total Islamic banking asset recorded up to RM 342 billion or 19.3\% of the total bank assets in Malaysia as at $31^{\text {st }}$ May 2012. It can be said that the Islamic banking system in Malaysia is growing from time to time. Today, more than 20 Islamic banks are operating in Malaysia comprising of local and international Islamic banks. The Islamic banking system has emerged as a competitor and a viable substitute for the conventional banking system during the last three decades. It is evidently true in the Muslim world where presently Islamic banking is striding in two separate fronts. On one side, efforts are underway to convert the entire banking system to be in accordance with the Islamic laws (Shariah). On the other side, a separate Islamic banking is allowed to operate parallel to conventional interest-based banks. 
Regarding personal loans, the Edge Malaysia (2013) reported that household indebtedness in Malaysia has grown from 33\% of the banking sector loans in 1998 to 55\% in 2011, representing 76.6\% of the Gross Domestic Product (GDP). The percentage of household debts to GDP in 2009 was $70 \%$ and in 2010, it was $75.8 \%$ and rose further to $80.5 \%$ in 2012 . In response to the overall problem of increasing household debts, BNM released a new set of guidelines hoping to alleviate the problem. BNM limits loan tenures, for instance, 10 years for personal loans and 35 years for housing loans (BNM Press Statement, 2013). Consequently, statistics from Bank Negara Malaysia showed that personal loan approval in 2012 was on a downward trend compared to 2011. The approval for a personal loans in January 2012 was RM954.8 million, down 29.8\% from RM1.36 billion a year ago and in 2010, RM 1.18 billion (The Edge Malaysia, 2012). BNM's new measures will, however, be felt in the personal loan segment as they will lead to a significant increase in monthly loan repayment, resulting in lower affordability for borrowers. The personal loan segment is very profitable for banks because it provides a good return. This is one of the reasons why this topic is chosen by the researcher, especially from an Islamic perspective.

Observing the situation in Malaysia, with the continued positive growth of the economy, the loan segment also has a huge potential for growth. Household debts are the highest among developing countries in the region. Since BNM tightened the lending guidelines in 2010, personal loans granted by banks have been decreasing. Nevertheless, non-bank financial institutions (NBFIs) have been growing rapidly at a stronger pace (Bank Negara Malaysia, 2012). Perhaps, this is due to the increase in size and tenure of loans which have been practised by NBFIs. Regarding the problem concerning the decrease in the personal loans extended by banks compared to the loans by NBFI, there is a need to study personal loans, specifically Islamic personal financing. Consequently, this research is beneficial in ensuring consistency in the financing practices among banks and non-banks by attracting consumers to choose Islamic personal financing, especially to purchase the halal goods that are offered by Islamic banks.

\section{Literature Review}

The underlying theory used in this study is the Theory of Planned Behavior (TPB). In this study, the TPB model is modified to better explain the intention to use Islamic personal financing by adding 
two new independent variables, namely religious obligation and religiosity as a new approach within the context of Islamic financing. Thus, it is expected that these variables will be a significant influence on the intention to use Islamic personal financing. These claims were supported by previous studies (Metwally, 1996; Okumus, 2005; Amin, Abdul Rahman, Chooi \& Sondoh, 2011; Alam \& Sayuti 2012).

According to the Theory of Reasoned Action (TRA), the term intention refers to a person's readiness to do or perform a particular behavior as a result of two influential factors, namely attitude and subjective norm. Many studies have investigated the antecedent factors that affect a person's behavioral intention to buy products or services. For instance, Wahyuni, Sakur \& Arifin (2013) examined that all of the variables, namely knowledge, attitude and social norms had positive effects on the intention to use Islamic banking products. Moreover, Amin et al. (2011) showed that three determinants are significant in influencing the intention to use Islamic personal financing, namely attitude, social influence and pricing of Islamic personal financing.

Attitude refers to the evaluative effect of individuals' positive or negative feelings in order to perform a particular behavior (Fishbein \& Ajzen, 1975). Additionally, Taylor and Todd (1995) and Morris and Dillon (1997) stated that the more positive a person's behavioral attitude, the stronger the behavioral inclination. On the other hand, the more negative the attitude, the weaker the behavioral inclination. Numerous studies have proved that the significant effect of attitude on intention. For example, Azizi and Javidani (2010) examined the significant influence of attitude on measuring e-shopping intention in the Iranian perspective. Moreover, in the context of Islamic finance researches, a recent study by Alam et al. (2012) confirmed that attitude is an important factor in influencing the intention to undertake Islamic home financing among Muslims in the Klang Valley. Amin et al. (2011) also proved that attitude is a key determinant in influencing the intention to use Islamic personal financing. Furthermore, using the survey method, Taib Ramayah and Razak (2008) indicated a significant positive relationship between postgraduate students' attitude and Islamic partnership home financing in Malaysia. Overall, findings on attitude show its importance in predicting the behavioral intention of the consumers. Based on the above findings, attitude can be considered as an important part of predicting and describing the banking customer to subscribe to Islamic personal financing. 
Many previous studies referred to social influence as subjective norms. A subjective norm refers to an individual's perception of other people's opinions on whether he or she should perform or not a particular behavior (Ajzen, 1991). As declared by Hsu, Wang and Wen (2006), the more positive the subjective norm, the stronger the behavioral intention. The importance of a subjective norm has also been noted by Laohapensang (2009) who confirmed that a subjective norm has a positive effect on behavioral intention in influencing internet shopping by Thai consumers. In the Malaysian context, Gopi and Ramayah (2007) reported that subjective norm is an important predictor of the intention to use. In another study, Alam and Sayuti (2011) found that there is positive relationship between subjective norm and the intention to purchase halal food products in Malaysia. In the context of Islamic finance, previous studies showed that subjective norms have a direct impact on the intention to use Islamic personal financing (Amin et al., 2011). In addition, Taib et al. (2008) found that subjective norm was the most influential predictor of intention to use Islamic financing than attitude. However, studies on subjective norm as a predictor of intention have shown mixed results. It is reported in the study by Armitage and Conner (2001) that subjective norm is the weakest factor in the TPB. It is also related to research by Wilson (2008) who found that subjective norms weakly predicted the intention to do unethical behavior among business students. Consequently, this study has taken social influence into consideration and tries to understand its influence on university staff regarding banking products.

Perceived behavioral control is informed by beliefs about the individual's possession of the opportunities and resources needed to engage in the behavior (Ajzen, 1991). According to Fayolle (2007), perceived behavioral control refers to a person's perception of how easy or difficult it is to engage in a particular behavior, which may depend on past experiences, second-hand information and anticipated assistance and impediments. It is the extent to which a person feels he is able to enact the behavior. Instead, an increase of perceived behavioral control also will increase the perception of opportunity. Particularly, a number of empirical studies have found a significant relationship between perceived behavioral control and intention. For instance, the study by Abadi et al. (2012) indicated that the behavioral intention to use mobile banking is positively affected mainly by perceived behavioral control. A similar finding was also found in the study by Laohapensang, (2009); its results provided evidence of the significant effect of perceived behavioral control on behavioral 
intention of influencing internet shopping among Thai consumers in Thailand. In Malaysia, other studies have also proved that perceived behavioral control is positively related to behavioral intention. For example, the study by Alam et al. (2012) found that perceived behavioral control is a significant factor on the intention to undertake Islamic home financing among Muslims in the Klang valley. Another study by Alam and Sayuti (2011), perceived behavioral control was found to be positively related to intention to purchase halal food products in Malaysia. A similar finding was also found in the study by Siang and Weng (2011) which provides evidence on the significant effect of perceived behavioral control on behavioral intention in using Islamic banking products and services. Since previous studies have proposed that perceived behavioral control positively influences behavioral intention, this study took perceived behavioral control into consideration.

By definition, religious obligation refers to the role of religion in affecting an individual's choice or activities (Amin et al., 2011). Several reviews of Islamic banking have confirmed the importance of Shari'ah-compliant products with customers' bank selection. The greater the adherence to Shari'ah the greater is the possibility of an individual using Islamic banking products. It is expected that Shari'ah compliance could affect the use of Islamic personal financing. In other words, religious obligation in this study can be defined as a Shari'ah compliant product. The measures of religius obligation involve the perception to comply with the underlying Islamic principles such as riba-free, investment in Halal business and equal distribution of wealth (Butt, Ahmed, Altaf, Jaffer and Mahmood 2011). An Islamic bank needs to adhere to Islamic principles, values and goals when offering its products. This adherence by the bank can in turn affect one's decision to seek Islamic banking products. Most studies conducted in Malaysia with regard to Islamic banking dominantly have focused on choice criteria and patronage factors. A few researches have focused directly on examining the relationship of religious obligation with behavioral intention. More recently, a study conducted by Yusoff, Kamdari and Masri (2013) showed that there is a significant relationship between the acceptances of AITAB among consumers and religious obligation, which is shown as an important criteria in choosing the AITAB facility. A study by Amin (2012) concluded that religious obligation was a stronger determinant for the probability of Islamic credit card usage intention. Importantly, its results were in consonance with the Islamic religion and the Islamic worldview. 
Nevertheless, in relation to this study, the recent study by Amin et al. (2011) found that religious obligation was negatively related to the intention to use Islamic personal financing, which means the greater the religious obligation, the more likely that Islamic personal financing will not be utilized by bank customers. They explained that their finding was not in line with the findings of past studies (Omer, 1992; Metwally, 1996; Metawa \& Almossawi, 1998) because a possiblity for the contrary results may be attributed to the items included in the research questionnaire, which had been adapted from past studies to better reflect the study context of Islamic personal financing. In view of this, this study suggests that the greater the adherence to Shariah principle (religious obligation), the more favourable the intention is.

Religiosity is defined as the intrinsic religious orientation in which religion provides the individual with a meaning-endowing framework in terms of which life is understood. In this study, religiosity is defined as a consumer's ethical beliefs and this will be reflected in their daily conduct and commitment (Vitell \& Paolillo, 2003). Religiosity is a very subjective issue and to measure this variable is not easy as it is determined by the person's spirituality. Being a religious person does not mean that the person has to engage in Islamic banking facilities, and in this study, the person's religiosity will be evaluated to see if there is an influence on the person's attitude towards engaging in Islamic banking facilities.

According to Alam et al. (2011), although religion exercises a powerful influence over the personal and social behavior of human beings, research in this area is limited. Overall, all previous studies supported that people who have held certain values of religion are able to influence their actions and decisions. Moreover, Othman and Owen (2001) concluded that cultural and religious factors were identified as the most influential factors that affected Islamic banking adoption in Kuwait. Another study, by Wakhid and Efrita (2007), also stated religious factor as the key factor that would influence Islamic banking adoption.

In the Malaysian context, a study by Asari et al. (2011) revealed that religious value appears to be the most important factor in influencing customers to patronize Islamic banks in the East Coast of Peninsular Malaysia. Similarly, the importance of religiosity is also emphasized by researchers (Wan-Ahmad, Abdul Rahman, Ali \& Che-Seman 2008) who conducted a survey of 480 working Malay Muslims in the Klang valley. They found that religiosity was a motivating factor for them to 
patronize Islamic banks. Most studies were conducted with regard to the choice criteria and patronage factors of Islamic banking. Overall, all previous studies supported that people who have held certain values of religion were able to influence their actions and decisions. Religiosity is taken as a factor of the TPB model and it is expected to have a positive influence on intentional behavior which will increase the intention level of engaging in Islamic banking facilities, especially Islamic personal financing.

\section{Methodology}

This study relied primarily on self-administered questionnaires. Validated scales from previous research (Taib et al., 2008; Venkatesh \& Davis, 2000; Taylor \& Todd, 1997; Metwally, 1996; Alam et al., 2011) were used to measure the variables of interest. These scales were validated and their high reliability reported for each. All of these items were modified for Islamic personal financing usage. The population of this study consisted of 3,530 UUM staff, including academicians (1468) and administrative staff $(2,062)$. According to Krejcie and Morgan (1970) as quoted in Sekaran (2003), the sample size of this study was 346 based on a given population. Based on the Two Stage Cluster Sampling, the UUM staff were divided into four clusters which are departments, institutes/ units, centers and colleges (clusters). After the total number of UUM staff for each cluster had been identified, the samples in the clusters would be chosen randomly, so that all employees in the clusters were included in the sample. Out of the 400 questionnaires distributed, 308 responses were received resulting in a response rate of $77.0 \%$.

\section{Findings}

In terms of data analysis, the data were analyzed using the Independent Groups T-Test, Analysis of Variance (ANOVA) and Multiple Linear Regression. Table 1 shows the profiles of the respondents in this study using the Independent Groups T-Test and Analysis of Variance (ANOVA). The respondents were predominantly female, constituting 66 percent of the respondents. The majority of the respondents were between $31-40$ years old $(42.9 \%)$, followed by the $20-30$ year olds $(32.5 \%)$ and the $41-50$ year olds $(22.1 \%)$, while the rest were above 50 year olds (2.6\%). In terms of higher education level, the majority of them had SPM/STPM qualification, with a percentage of 30.2, 
followed by $20.8 \%$ with Bachelor degrees and $20.1 \%$ with master's degree. Meanwhile, the percentages of the respondents who had diplomas and PhD/DBA degree qualification were $14.9 \%$ and $14.0 \%$ respectively. The results also indicated that the majority of the respondents were administrative staff $(70.5 \%)$, while the rest were academicians (29.5\%). With regards to monthly income level, $36.7 \%$ of the respondents earned between RM 2,001 and RM 4,000, followed by the respondents who received income below RM 2,000 (32.8\%). The percentages of the respondents who earned between RM 4,001 and RM 6,000 was $21.1 \%, 7.5 \%$ of the respondents received income between RM 6,001 and RM 8,000, while a small number of respondents earned RM 8,000 and above. In terms of working experience in UUM, $30.2 \%$ of the respondents had less than 5 years of experience, while $28.6 \%$ had between 5 and 10 years of working experience and $24.7 \%$ of the respondents had between 11 and 15 years of working experience. Only a small number of the respondents had between 16 and 20 years, and above 21 years of working experience, which were $8.1 \%$ and $8.4 \%$ respectively.

Table 1

Profile of the Respondents $(N=308)$

\begin{tabular}{llrr}
\hline \multicolumn{1}{c}{ Items } & \multicolumn{1}{c}{ Category } & $\begin{array}{r}\text { Frequency } \\
(\mathrm{N}=308)\end{array}$ & $\begin{array}{r}\text { Percentage } \\
(\%)\end{array}$ \\
\hline Gender & Male & 104 & 33.8 \\
& Female & 204 & 66.2 \\
Age & Below 30 years & 100 & 32.5 \\
& 31 - 40 years & 132 & 42.9 \\
& 41 - 50 years & 68 & 22.1 \\
Highest Education & above 51 years & 8 & 2.6 \\
Level & Secondary School (SPM/ & 93 & 30.2 \\
& STPM) & 46 & 14.9 \\
& Diploma & 64 & 20.8 \\
& Bachelor Degree & 62 & 20.1 \\
& Masters & 43 & 14.0 \\
& DBA/ PhD & & \\
& Academician & 91 & 29.5 \\
& Non-academician & 217 & 70.5 \\
\hline
\end{tabular}




\begin{tabular}{llrr}
\hline \multicolumn{1}{c}{ Items } & \multicolumn{1}{c}{ Category } & $\begin{array}{r}\text { Frequency } \\
(\mathrm{N}=308)\end{array}$ & $\begin{array}{r}\text { Percentage } \\
(\%)\end{array}$ \\
\hline Monthly Income & Below RM 2,000 & 101 & 32.8 \\
Level & RM 2,001 - RM 4,000 & 113 & 36.7 \\
& & 65 & 21.1 \\
& RM 4,001 - RM 6,000 & 23 & 7.5 \\
& RM 6,001 - RM 8,000 & 6 & 1.9 \\
& RM 8,001 above & & \\
Working Experience & Less than 5 years & 93 & 30.2 \\
& 5- 10 years & 88 & 28.6 \\
& 11 - 15 years & 76 & 24.7 \\
& 16 - 20 years & 25 & 8.1 \\
& Above 21 years & 26 & 8.4 \\
\hline
\end{tabular}

Table 2 shows the results of the Multiple Linear Regression applied in this study. It is evidenced that attitude has a significant influence on the intention to use Islamic personal financing at the 5 percent significance level $(B=0.166$, sig. $=0.003)$. This means that a one unit increase in attitude will positively increase 0.166 unit of intention to use. Nevertheless, social influence did not prove to be a significant predictor on the intention to use as indicated by the path model $(\mathrm{B}=$ 0.002 , sig. $=0.959$ ). It means that a one unit decrease in social influence will decrease 0.002 unit of intention to use. The results of the multiple linear regressions further indicated that perceived behavioral control had a significant influence on the intention to use Islamic personal financing at the 1 percent significance level $(B=0.521$, sig. $=0.000)$. It means that a one unit increase in perceived behavioral control will positively increase 0.521 unit of the intention to use Islamic personal financing. Moreover, the results also indicated that religious obligation also had a significant influence on the intention to use Islamic personal financing at the 5 percent significance level $(B=$ 0.129 , sig. $=0.011$, which means that a one unit increase in religious obligation will positively increase 0.129 unit of the intention to use Islamic personal financing. Religiosity also proved to be a predictor of the intention to use $(B=0.223$, sig. $=0.000)$, which means that a one unit increase in religiosity will positively increase 0.223 unit of the intention to use. With respect to the overall model, the $R$ square $\left(R^{2}\right)$ was 0.646 indicating that $64.6 \%$ of the variance in the intention to use Islamic personal financing among the UUM staff could be explained by the five independent variables. 
IJMS 22, Special Issue 47-60 (2015)

Table 2

Results of Multiple Regression Analysis

\begin{tabular}{|c|c|c|c|c|c|}
\hline & \multicolumn{2}{|c|}{$\begin{array}{c}\text { Unstandardized } \\
\text { Coefficients }\end{array}$} & \multirow{2}{*}{$\begin{array}{c}\text { Standardized } \\
\text { Coefficients } \\
\text { Beta }\end{array}$} & \multirow[t]{2}{*}{$\mathrm{t}$-value } & \multirow[t]{2}{*}{ Sig. } \\
\hline & B & $\begin{array}{l}\text { Std. } \\
\text { Error }\end{array}$ & & & \\
\hline (Constant) & -.138 & .232 & & -.595 & .552 \\
\hline Attitude & .166 & .055 & .148 & 3.000 & $.003^{* *}$ \\
\hline Social Influence & .002 & .039 & .002 & .051 & .959 \\
\hline Perceived Behavioral Control & .521 & .049 & .513 & 10.691 & $.000^{* *}$ \\
\hline Religious Obligation & .129 & .051 & .132 & 2.546 & $.011^{*}$ \\
\hline$\underline{\text { Religiosity }}$ & .223 & .054 & .168 & 4.135 & $.000^{* *}$ \\
\hline
\end{tabular}

\section{Discussions}

This study depicted that four constructs, attitude, perceived behavioral control, religious obligation and religiosity have significant influence on the intention to use Islamic personal financing. Perceived behavioral control proved to be a strong predictor of the intention to use Islamic personal financing. It is followed by religiosity, attitude and religious obligation. However, social influence has no significant influence on the intention to use Islamic personal financing. Finally, the result has shown that the independent variables explain $64.6 \%$ of the variance in the intention to use Islamic personal financing. This study confirmed that perceived behavioral control is the main predictor in influencing consumer intention in undertaking Islamic personal financing. It means that the key important factor of UUM staff's intention to take Islamic personal financing is due to their ability, knowledge and resources. In other words, they have the necessary resources such as time and money, capability such as ability, knowledge and selfefficacy in successfully performing Islamic personal financing. This finding is consistent with previous studies.

\section{Conclusion}

As the aspiration of the Government is to develop Malaysia as Asia's Islamic financial hub, the relevant authorities in the banking sectors have to encourage the undertaking of Islamic banking products to be 
at par with the conventional banks. Similarly, for personal financing facilities, the Government should assist first-time buyers through its policies to encourage the public to choose Islamic personal financing. In tandem, the Islamic banking institutions also need to offer their support to stimulate the market by providing comprehensive, better quality of products and services to the customers. This is important as customers, particularly, in urban areas will prefer banking institutions which offer better quality of products and services. In addition, the target to transform Malaysia into a high income nation status by 2020 needs significant support from all parties, particularly, the Islamic banking institutions and financial sectors. Fortunately, the existing Islamic personal financing is receiving positive response among the public. This is due to the emergence of more attractive Shari'ah contracts for personal financing offered by the Islamic banking institutions.

\section{References}

Abadi, H. R. D., Ranjbarian, B., \& Zade, F. K. (2012). Investigate the customers' behavioral intention to use mobile banking based on TPB, TAM and perceived risk (A case study in Meli Bank). International Journal of Academic Research in Business and Social Sciences, 2(10).

Ajzen, I. (1991). The Theory of Planned Behavior. Organizational Behavior and Human Decision Processes, 50, 179-211.

Alam, S. S., \& Sayuti, N. M. (2011). Applying the Theory of Planned Behavior (TPB) in halal food purchasing. International Journal of Commerce and Management, 21(1), 8-20.

Alam, S. S., Janor, H., Zanariah, Che-Wel, C. A., \& Ahsan, M. N. (2012). Is religiosity an important factor in influencing the intention to undertake Islamic home financing in Klang Valley? World Applied Sciences Journal, 19(7), 1030-1041.

Amin, H., Abdul-Rahman, A. R., Chooi Hwa, A. M., \& Sondoh, Jr. S. L. (2011). Determinants of customers' intention to use Islamic personal financing: The case of Malaysian Islamic banks. Journal of Islamic Accounting and Business Research, 2(1), 22-42.

Armitage, C. J., \& Conner, M. (2001). Efficacy of the Theory of Planned Behavior: A meta-analytic review. British Journal of Social Psychology, 40, 471-479.

Asari, F. F., Idris, A. R., Januri, S. S., Jusoff, K., Muhammad-Naziman, K. N., \& Muhammad, N. (2011). Religious value as the main influencing factor to customers patronizing Islamic bank. World Applied Sciences, 12, 8-13. 
Azizi, S., \& Javidani, M. (2010). Measuring e-shopping intention: An Iranian perspective. African Journal of Business Management, 4 (13), 2668-2675.

Bank Negara Malaysia (2012). Monetary and financial conditions: White Box Article. Annual Report 2012, pp. 67-69.

BNM Press Statement. (2013). Measures to further promote a sound and sustainable household sector. Retrieved July 5, 2013. Available at: http://www.bnm.gov.my/

Butt, I., Ahmed, H., Altaf, M., Jaffer, K., \& Mahmood, J. (2011). Barriers to adoption of Islamic banking in Pakistan. Journal of Islamic Marketing, 2 (3), 259-273.

Fayolle, A. (2007). Entrepreneurship and new value creation: The dynamic of the entrepreneurial process. England: Cambridge University Press.

Fishbein, M., \& Ajzen, I. (1975). Belief, attitude, intention and behavior: An introduction to theory and research. Addison-Wesley, Reading: MA.

Gopi, M., \& Ramayah, T. (2007). Applicability of Theory of Planned Behavior in predicting intention to trade online: Some evidence from a developing country. International Journal of Emerging Markets, 2(4), 348-60.

Hsu, T. H., Wang, Y. S., \& Wen, S. C. (2006). Using the decomposed Theory of Planned Behaviour to analyse consumer behavioural intention to use mobile coupons. Journal of Targeting, Measurement and Analysis for Marketing, 14(4), 309-324.

Laohapensang, O. (2009). Factors influencing Internet shopping behaviour: A survey of consumers in Thailand. Journal of Fashion Marketing and Management, 13(4), 501-51.

Malaysian Business. (2013). Islamic banking: How it all began, p. 60-61

Metawa, S. A., \& Almossawi, M. (1998). Banking behaviour of Islamic bank customers: Perspectives and implications. International Journal of Bank Marketing, 16(7), 299-313.

Metwally, M. (1996). Attitudes of Muslims towards Islamic banks in a dual banking system. American Journal of Islamic Finance, 6, $11-17$.

Morris, M. G., \& Dillon, A. (1997). How user perceptions influence software use. IEEE Software, 14 (4), 58-65.

Okumus, S. H. (2005). Interest free banking in Turkey: A study of customer satisfaction and bank selection criteria. Journal of Economic Cooperation, 26(4), 51-86.

Omer, H. (1992). The implication of Islamic beliefs and practice on Islamic financial institutions in the UK. PhD dissertation, Loughborough University, Loughborough. 
Othman, A., \& Owen, L. (2001). Adopting and measuring customers service quality (SQ) in Islamic banks: A case study in Kuwait Finance House. International Journal of Islamic Financial Services, $3(1), 1-26$.

Sekaran, U. (2003). Research methods for business: A skill building approach (4th ed.). New York, NY: Wiley.

Siang, L. C., \& Weng, L. K. (2011). Factors affecting non-Muslim consumers' towards intention to use Islamic banking products and services. Paper presented at The 2011 Las Vegas International Academic Conference Las Vegas, Nevada USA.

Taib, F. M., Ramayah, T., \& Razak, D. A. (2008). Factor influencing intention to use diminishing partnership home financing. International Journal of Islamic and Middle Eastern Finance and Management, 1(3), 235-48.

Taylor, S., \& Todd P. A. (1997). Understanding the determinants of consumer composting behavior. Journal of Social Applied Psychology, 27, 602-28.

Taylor, S., \& Todd, P. A. (1995). Understanding Information Technology usage: A test of competing models. Information Systems Research, 6(2), 144-176.

The Edge Malaysia. (2012). BNM measures taking effect on personal loans. Retrieved from http://www.theedgemalaysia.com/businessnews/216283bn m-measures-taking-effect-on-personal-loans. html

The Edge Malaysia. (2013). Keeping the lid on household debt. Retrieved from http://www.theedgemalaysia.com/commentary/245383keeping-the-lid-on-household-debt.html

Venkatesh, V., \& Davis, F. D. (2000). A theoretical extension of the Technology Acceptance Model: Four longitudinal field studies. Management Science, 46(2), 186-204.

Vitell, S. J., \& Paolillo, J. G. P. (2003). Consumer ethics: The role of religiosity. Journal of Business Ethics, 46(2), 151-162.

Wahyuni, S., Sakur, \& Arifin, T. (2013, November 4-5). Knowledge as an antecedent variable of intention to use Islamic banking product. Paper presented at the $2^{\text {nd }}$ Asean Academic Society International Conference: International Conference on Business, Economics and Social Science, Bangkok.

Wakhid, S. C., \& Efrita, S. (2007). Adapting Islamic banks' CARTER Model: An empirical study in Riau's Syariah banks, Indonesia.

Wan-Ahmad, W. M., Ab-Rahman, A., Ali, N. A., \& Che-Seman, A. (2008). Religiosity and banking selection criteria among Malays in Lembah Klang. Journal of Syariah, 16(2), 279-304. 
IJMS 22, Special Issue 47-60 (2015)

Wilson, B. A. (2008). Predicting intended unethical behavior of business students. Journal of Education for Business, 187-195.

Yusoff, R., Md-Kamdari, N. A., \& Masri, D. N. (2013, September 5). Selection factors of the acceptance al-Ijarah Thumma al-Bay (AITAB) in Shah Alam. Paper presented at the $5^{\text {th }}$ Islamic Economics System Conference (iECONS 2013), Kuala Lumpur, Malaysia. 